\title{
Genotype X Environment Interaction and Stability Analysis for Grain Yield of Bread Wheat (Triticum aestivum) Genotypes Under Low Moisture Stress Areas of Ethiopia
}

\author{
Alemu Dabi ${ }^{1, ~}$, Gadisa Alemu ${ }^{1}$, Negash Geleta ${ }^{1}$, Abebe Delessa ${ }^{1}$, Tafesse Solomon ${ }^{1}$, \\ Habtemariam Zegaye ${ }^{1}$, Dawit Asnake ${ }^{1}$, Bayisa Asefa ${ }^{1}$, Rut Duga ${ }^{1}$, Abebe Getamesay ${ }^{1}$, \\ Demeke Zewudu ${ }^{1}$, Zerihun Tadesse ${ }^{1}$, Bedada Girma ${ }^{2}$, Ayele Badebo ${ }^{2}$, Bekele Abeyo ${ }^{2}$ \\ ${ }^{1}$ Ethiopian Institute of Agricultural Research, Kulumsa Agricultural Research Center, Asella, Ethiopia \\ ${ }^{2}$ CYMMIT Ethiopia Office, Addis Ababa, Ethiopia
}

Email address:

alemudabi2009@gmail.com (A. Dabi)

${ }^{*}$ Corresponding author

\section{To cite this article:}

Alemu Dabi, Gadisa Alemu, Negash Geleta, Abebe Delessa, Tafesse Solomon, Habtemariam Zegaye, Dawit Asnake, Bayisa Asefa, Rut Duga, Abebe Getamesay, Demeke Zewudu, Zerihun Tadesse, Bedada Girma, Ayele Badebo, Bekele Abeyo. Genotype X Environment Interaction and Stability Analysis for Grain Yield of Bread Wheat (Triticum aestivum) Genotypes Under Low Moisture Stress Areas of Ethiopia. American Journal of Plant Biology. Vol. 6, No. 3, 2021, pp. 44-52. doi: 10.11648/j.ajpb.20210603.12

Received: March 11, 2021; Accepted: April 16, 2021; Published: July 21, 2021

\begin{abstract}
A multi-locations' experiments were carried out from 2018 to 2019 main cropping seasons in moisture stress areas of Ethiopia to estimate the genotype $\mathrm{x}$ environment interaction and to select stable and adaptable variety/ies for grain yield of bread wheat. The genotypes consisted of 23 genotypes and two standard checks arranged in alpha lattice design replicated three times. Data were taken for agronomic traits and diseases. Analysis of variances and stability analysis were carried out for grain yield using $\mathrm{R}$ software. Combined analysis of variance showed a highly significant $(\mathrm{p} \leq 0.01)$ difference among the genotypes, locations, and GEI for grain yield suggesting a differential response of genotypes across testing environments. The grand mean yield over nine environments was $5251.90 \mathrm{~kg} \mathrm{ha}^{-1}$ and the mean yield of genotypes across nine environments ranged from $1539.29 \mathrm{~kg} \mathrm{ha}^{-1}$ in 2018 at Dhera to $7621.87 \mathrm{~kg} \mathrm{ha}^{-1}$ in 2018 at Kulumsa, respectively. The recorded mean yield of the standard check Deka $\left(5066.543 \mathrm{~kg} \mathrm{ha}^{-1}\right)$ and Ogolcho $\left(4018.39 \mathrm{~kg} \mathrm{ha}^{-1}\right)$ was below the grand mean yield of genotypes across environments. The Genotypes ETBW 9136 (5731.79 $\left.\mathrm{kg} \mathrm{ha}^{-1}\right)$, ETBW 9139 (5844.87 $\left.\mathrm{kg} \mathrm{h}^{-1}\right)$, ETBW 9646 $\left(5754.01 \mathrm{~kg} \mathrm{ha}^{-1}\right)$, ETBW9172 (5634.01 kg ha $)$, ETBW9641 (5545.03 kg ha $\left.{ }^{-1}\right)$, ETBW 9080 (5545.31 kg ha $\left.{ }^{-1}\right)$ and ETBW9396 (5467.04 $\left.\mathrm{kg} \mathrm{ha}^{-1}\right)$ gave the highest mean grain yield across environments, whereas the standard check Ogolcho recorded lowest mean grain yield across environments. The first four principal components of the GEI explained $85.6 \%$ of the variation. Additive main effects and multiplicative interaction (AMMI) stability parameters revealed that the genotypes ETBW 9080 (G11), ETBW 9172 (G12), ETBW 9646 (G19), ETBW 9396 (G13), ETBW 9452 (G14), ETBW 9136 (G5) and ETBW 9139 (G6) were high yielder and more stable inferring little interaction of genotypes with the environment whereas Ogolcho (G25), ETBW 9119 (G3), ETBW 9647 (G20) and ETBW 9065 (G8) was low yielder and unstable suggesting high interaction with the environments. Based on stability parameters and other agronomic traits, the genotypes viz. ETBW 9396 (G13) and ETBW 9080 (G11), were proposed for variety verification and possible release in 2021.
\end{abstract}

Keywords: Ethiopia, Genotype by Environment Interaction, Grain Yield, Moisture Stress Areas, Stability Analysis, Triticum Aestivum

\section{Introduction}

Wheat (Triticum spp.) is one of the most important cereal crops cultivated in Ethiopia. The production and productivity of wheat have increased by $14 \%$ due to the use of full packages for the last decade in Ethiopia [9]. The current wheat productivity is 2.7 tons per hectare but 
the potential yield could be more than 5.0 tons per hectare $[3,13]$. However, due to a higher increment in demands, about $37 \%$ ( 1.7 million tons) wheat grain deficit was observed during the 2018 budget year in Ethiopia (https://www.world-grain.com/articles/11880-ethiopiaswheat-production-to-increase/accessed in Nov. 2019). The yield gap observed could be attributed to different factors of which is lack of high yielder varieties sustainably tolerant to diseases and pests, tolerant to low $\mathrm{pH}$ and waterlogged areas and lack of use of full packages and knowledge of production in the farming communities. The Varietal differences in relation to $\mathrm{Al}$ tolerance exist in wheat; and the integrated use of all the available resources including acid tolerant and crop species, which improve and sustain soil and agricultural productivity, is of great practical significance [12]. Biotic factors viz. fungal diseases, rusts (Puccinia. spp.) are the devastating rust diseases which highly affecting wheat production of wheat in Ethiopia [18].

Multi-environment trials are important in plant breeding for evaluating genotypes for their overall stability and adaptability in the presence of genotype by environment (GE) interaction. An understanding of GE interaction is important at all stages of plant breeding, including ideotype design, parent selection, selection based on traits, including grain yield [19]. The $\mathrm{G} \times \mathrm{E}$ study is important in presence various agro-ecologies. Significant $G \times E$ interaction is a consequence of variations in the extent of differences among genotypes in diverse environments (called as a qualitative or rank changes) or variations in the comparative ranking of the genotypes (called as a quantitative or absolute differences between genotypes) $[5,6,8]$.

Low moisture stress is becoming important in bread wheat producing areas of Ethiopia. In view of the problems, two product concepts (low moisture areas and high moisture areas) were designed in wheat breeding program at Kulumsa Agricultural Research Center and genotypes were selected based on the different agronomic traits viz. low sensitivity to low moisture stresses, early maturity and other agronomic traits. Therefore, a multilocations trials were designed with the objectives to estimate the magnitude of genotype by environment interactions; and to select best genotypes with stable and adaptable to the tested environments.

\section{Materials and Methods}

\subsection{Experimental Sites' Descriptions}

The experiments were conducted at nine environments viz. Dhera, Melkasa, Asasa, Kulumsa and Atsela during 2018 and at Dhera, Melkasa, Kulumsa and Asasa during 2019 cropping season. The descriptions of the locations are listed in Table 1.

Table 1. List of test locations and their descriptions.

\begin{tabular}{|c|c|c|c|c|c|c|c|c|c|}
\hline \multirow{3}{*}{$\begin{array}{l}\text { Experimental } \\
\text { site }\end{array}$} & \multicolumn{2}{|c|}{ Geographic position } & \multirow{3}{*}{ Altitude } & \multicolumn{3}{|l|}{2018} & \multicolumn{3}{|l|}{2019} \\
\hline & \multirow{2}{*}{ Latitude } & \multirow{2}{*}{ Longitude } & & \multicolumn{2}{|c|}{ Temperature $\left({ }^{\circ} \mathrm{C}\right)$} & \multirow{2}{*}{$\begin{array}{l}\text { Rain fall } \\
(\mathrm{mm})\end{array}$} & \multicolumn{2}{|c|}{ Temperature $\left({ }^{\circ} \mathrm{C}\right)$} & \multirow{2}{*}{$\begin{array}{l}\text { Rainfal } \\
\text { (mm) }\end{array}$} \\
\hline & & & & Min & $\operatorname{Max}$ & & Min & $\operatorname{Max}$ & \\
\hline Kulumsa & $08^{\circ} 01^{\prime} 10^{\prime \prime} \mathrm{N}$ & $39^{\circ} 09^{\prime} 11^{\prime \prime} \mathrm{E}$ & 2200 & 11.85 & 23.48 & 850 & 11.0 & 24.0 & 939.0 \\
\hline Asasa & $07^{\circ} 07^{\prime} 09^{\prime \prime} \mathrm{N}$ & $39^{\circ} 11^{\prime} 50^{\prime \prime} \mathrm{E}$ & 2340 & 6.92 & 18.11 & 640 & 7.0 & 21.0 & 640.0 \\
\hline Dhera & $08^{\circ} 19^{\prime} 10^{\prime \prime} \mathrm{N}$ & $39^{\circ} 19^{\prime} 13^{\prime \prime} \mathrm{E}$ & 1650 & 14.00 & 27.80 & 680 & - & - & - \\
\hline Melkasa & $08^{\circ} 24^{\prime} \mathrm{N}$ & $39^{\circ} 12^{\prime} \mathrm{E}$ & 1550 & 13.60 & 28.60 & 763 & - & - & - \\
\hline
\end{tabular}

Note: Sources (KARC; 2019; MARC, 2019)

\subsection{Experimental Design and Data Management}

Twenty-five genotypes including two standard checks were grown in Alpha-Lattice Design with three replications (Table 2). Each experimental unit consisted of six rows of $2.5 \mathrm{~m}$ length with $20 \mathrm{~cm}$ spacing between rows; $1 \mathrm{~m}$ and $1.5 \mathrm{~m}$ spaces were left between adjacent plots and replications, respectively. Data were collected from the entire plot for the parameters days to heading, days to maturity, grain yield, 1000 kernel weight, hectoliter weight, and from randomly sampled plants for the character; plant height. A seed rate of $125 \mathrm{kgha}^{-1}$ was used at all locations. Fertilizers were applied based on the specific site recommendations and weeding were done uniformly to all plots in each location as necessary. Yellow rust (Puccinia striformisf. sp. tritici.) and stem rust (P. graminis) data, were recorded using the modified Cobb scale [15]. Disease severity was estimated which was used to determine the percentage of possible tissue infected and the maximum disease severity and reaction record were taken at each testing location for each genotype.

\subsection{Statistical Analyses}

Additive main effects and multiplicative interaction (AMMI) method integrates analysis of variance and principal components into a unified approach $[2 ; 11]$. AMMI method first fits the additive main effects of genotypes and environments by the usual analysis of variance and then describes the non-additive part, genotype by environment interaction, by principal component analysis. Data were subjected to analysis after checking for required assumptions of normality, homogeneity of variance using respective tests. The AMMI analysis was performed using the model suggested by Gauch and Zobel [11] for genotypes and environments is:

$$
Y i j=\mu+g i+e j+\sum_{k=1}^{n} \Lambda_{k} a_{i k} y_{j k}+e_{i j}
$$


Table 2. List of studied bread wheat genotypes.

\begin{tabular}{|c|c|c|}
\hline Entry No. & Genotype & Pedigree \\
\hline G1 & DAKA & Check \\
\hline G2 & ETBW 9116 & $\begin{array}{l}\text { PFAU/MILAN/5/CHEN/AEGILOPS SQUARROSA (TAUS)//BCN/3/ } \\
\text { VEE\#7/BOW/4/PASTOR/6/KINGBIRD \#1 }\end{array}$ \\
\hline G3 & ETBW 9119 & $\begin{array}{l}\text { ELVIRA/5/CNDO/R143//ENTE/MEXI75/3/AE.SQ/4/2*OCI/6/VEE/PJN//KAUZ/3/PASTOR/7/TILHI/4/CR } \\
\text { OC_1/AE.SQUARROSA }(213) / / \mathrm{PGO} / 3 / \mathrm{CMH} 81.38 / 2 * \mathrm{KAUZ/8/PICAFLOR} \mathrm{\# 2}\end{array}$ \\
\hline G4 & ETBW 9128 & FRNCLN*2/BECARD \\
\hline G5 & ETBW 9136 & $\begin{array}{l}\text { 92.001E7.32.5/SLVS/5/NS-732/HER/3/PRL/SARA//TSI/VEE\#5/4/ } \\
\text { FRET2/6/SOKOLL/3/PASTOR//HXL7573/2*BAU }\end{array}$ \\
\hline G6 & ETBW 9139 & KA/NAC//TRCH/5/W15.92/4/PASTOR//HXL7573/2*BAU/3/WBLL1 \\
\hline G7 & ETBW 9149 & $\begin{array}{l}\mathrm{PRL} / 2 * \mathrm{PASTOR} / 6 / \mathrm{TRAP} \# 1 / \mathrm{BOW} / 3 / \mathrm{VEE} / \mathrm{PJN} / / 2 * \mathrm{TUI} / 4 / \mathrm{BAV} 92 / \mathrm{RAYON} / 5 / \mathrm{KACHU} \# 1 \\
\text { FALCIN/AE.SQUARROSA }(312) / 3 / \mathrm{THB} / \mathrm{CEP} 7780 / / \mathrm{SHA} 4 / \text { LIRA/4/ FRET2/5/DANPHE }\end{array}$ \\
\hline G8 & ETBW 9065 & $\begin{array}{l}\text { \#1/11/CROC_1/AE.SQUARROSA (213)//PGO/10/ } \\
\text { ATTILA*2/9/KT/BAGE//FN/U/3/BZA/4/TRM/5/ALDAN/6/SERI/7/VEE\#10/8/OPATA }\end{array}$ \\
\hline G9 & ETBW 9077 & SHORTENED SR 26 TRANSLOCATION//2*WBLL $1 * 2 /$ KKTS/3/BECARD \\
\hline G10 & ETBW 9078 & SWSR22T.B./2*BLOUK \#1//WBLL1*2/KURUKU \\
\hline G11 & ETBW 9080 & KACHU//WHEAR/SOKOLL \\
\hline G12 & ETBW 9172 & ND643/2*WBLL1//KACHU \\
\hline G13 & ETBW 9396 & BOUSHODA-1/4/CROC-1/AE.SQUARROSA (205)//KAUZ/3/SASIA \\
\hline G14 & ETBW 9452 & REBWAH-19/HAAMA-14 \\
\hline G15 & ETBW 9543 & $\begin{array}{l}\text { KFA//PBW343/PASTOR/3/PBW343*2/KUKUNA/4/PBW343*2/KUKUNA*2//FRTL/PIFED/5/PBW343*2/ } \\
\text { KUKUNA*2//FRTL/PIFED }\end{array}$ \\
\hline G16 & ETBW 9545 & $\begin{array}{l}\text { ATTILA*2/PBW65*2//MURGA/4/MUU } \\
\# 1 / / \mathrm{PBW} 343 * 2 / \mathrm{KUKUNA} / 3 / \mathrm{MUU} / 5 / \mathrm{ATTILA} 2 / \mathrm{PBW} 65 / / \mathrm{MURGA}\end{array}$ \\
\hline G17 & ETBW 9641 & $\begin{array}{l}\text { MELON//FILIN/MILAN/3/FILIN/4/PRINIA/PASTOR//HUITES/3/MILAN/OTUS//ATTILA/3*BCN/5/MEL } \\
\text { ON//FILIN/MILAN/3/FILIN }\end{array}$ \\
\hline G18 & ETBW 9642 & SOKOLL/3/PASTOR//HXL7573/2*BAU/4/WHEAR/SOKOLL \\
\hline G19 & ETBW 9646 & SOKOLL/3/PASTOR//HXL7573/2*BAU/4/PARUS/PASTOR \\
\hline G20 & ETBW 9647 & SOKOLL/3/PASTOR//HXL7573/2*BAU/4/MEX94.2.19//SOKOLL/WBLL1 \\
\hline G21 & ETBW 9648 & PUB94.15.1.12/FRTL//92.001E7.32.5/SLVS \\
\hline G22 & ETBW 9650 & SOKOLL/3/PASTOR//HXL7573/2*BAU/4/GLADIUS \\
\hline G23 & ETBW 9651 & KACHU $* 2 / 3 / \mathrm{ND} 643 / / 2 * \mathrm{PRL} / 2 * \mathrm{PASTOR}$ \\
\hline G24 & ETBW 9652 & PFUNYE \#1/KINGBIRD \#1 \\
\hline G25 & OGOLCHO & Check \\
\hline
\end{tabular}

Where, Yij is the mean yield of the $i^{\text {th }}$ genotype in the $j^{\text {th }}$ environment; $\mu$ is the general mean; gi is the $i^{\text {th }}$ genotypic effect; ej is the $\mathrm{j}^{\text {th }}$ location effect; $\lambda \mathrm{n}$ is the eigenvalue of the PCA axis $\mathrm{n} ; a_{i k}$ and $y_{j k}$ are the $\mathrm{i}^{\text {th }}$ genotype $\mathrm{j}^{\text {th }}$ environment PCA scores for the PCA axis $\mathrm{n}$; $e_{i j}$ is the residual; n' is the number of PCA axis retained in the model. Therefore, the interaction effect can be calculated as;

$$
(G X E) i j=y i j-y i-y j-y . .
$$

AMMI Stability Value (ASV): ASV indicates the distance from zero in the two-dimensional plot of IPCA1 score against IPCA2 score in the AMMI model [16].

The ASV was calculated using the formula suggested by purchase [16]

$$
A S V=\sqrt{\left[\frac{S S_{I P C A 1}}{S S_{I P C A 2}}(I P C A 1)^{2}\right]^{2}+(I P C A)^{2}}
$$

The larger the ASV value, either negative or positive, the more specifically adapted a genotype is to certain environments. Smaller ASV values indicate more stable genotypes across environments [16].

Where; $\mathrm{SS}_{\text {IPCA1 }}$ is sum of square of interaction principal component 1 and $\mathrm{SS}_{\mathrm{IPCA} 2}$ IS sum of square of interaction principal component 2.

Yield Selection Index (YSI): Stability is not the only parameter for selection as most stable genotypes and would not necessarily give the best yield performance. Therefore, based on the rank of mean grain yield of genotypes (rYi) across environments and rank of AMMI stability value (rASVi). A genotype with the least YSI is considered as the most stable [7]. Yield selection index (YSI) was calculated for each genotype as:

$$
Y S I=r A S V i+\mathrm{rYi}
$$

Eberhart and Russell regression model: The regression coefficient (bi) and deviation from regression $\left(\mathrm{S}^{2} \mathrm{~d}\right)$ of genotype mean across environments index were computed as suggested by [4]. The analysis was performed using $\mathrm{R}$ statistical software.

\section{Results and Discussion}

\subsection{Additive Main Effects and Multiple Interaction (AMMI) Model for Grain Yield}

Combined analysis of variance showed that highly significant $(p \leq 0.01)$ differences among the genotypes, 
environments, GEI and the first four Principal Components (PCs) for grain yield suggesting differences among environments and differential response of genotypes across testing environments (Table 3). The first four interaction principal components (IPCA) of the GEI explained $82.1 \%$ of the total variation and $40.5 \%$ is explained by IPCA1 followed by $16.7 \%, 15.2 \%$, and $9.7 \%$ for IPCA2, IPCA3, and IPCA4, respectively. The most accurate model for AMMI can be predicted by using the first two PCAs [10]. In this, the first two IPCAs were used to show genotype by environment interaction and placement on the biplots (Figure 1). The greater the IPCA scores (positive or negative) as it is a relative value, the more specifically adapted a genotype is to certain environments. The more IPCA scores approximate to zero, the more stable the genotype is across environments sampled [16; 1]. Accordingly, the genotypes ETBW 9080 (G11), ETBW 9172 (G12), ETBW 9646 (G19), ETBW 9396 (G13), ETBW 9452 (G14), ETBW 9136 (G5) and ETBW 9139 (G6) were relatively located near to the origin of the biplot and hence better stable (little interaction of genotypes with the environment) and widely adaptable genotypes across environments. Whereas the genotypes Ogolcho (G25), ETBW 9119 (G3), ETBW 9647 (G20) and ETBW 9065 (G8) far from the origin of biplot suggesting less stability (high interaction of genotypes with the environments) and have specific adaptability to certain environments.

Table 3. AMMI analysis of variance for grain yield $\left(\mathrm{kg} \mathrm{ha}^{-1}\right)$ of 25 bread wheat genotypes.

\begin{tabular}{llll}
\hline Source of variation & Df & Sum Squares & Mean Squares \\
\hline ENV & 8 & 2924185793 & $365523224 * * *$ \\
REP (ENV) & 18 & 29803986 & $1655777 * * *$ \\
GEN & 24 & 102570244 & $4273760 * * *$ \\
ENV x GEN & 192 & 274195518 & $1428102 * * *$ \\
PC1 & 31 & 110968396 & $3579625.7 * * *$ \\
PC2 & 29 & 45899417 & $1582738.5 * * *$ \\
PC3 & 27 & 41715720 & $1545026.7 * * *$ \\
PC4 & 25 & 26482907 & $1059316.3 * *$ \\
Residuals & 432 & 266347198 & 616544 \\
\hline
\end{tabular}

Note: Df- degrees of freedom.

\subsection{Mean Grain Yield Performances of the Genotypes Across the Tested Environments}

The mean grain yield of the 25 genotypes showed a wide range of variation in the different environments. The grand mean yield over nine environments was $5252 \mathrm{~kg} \mathrm{ha}^{-}$ 1 and the mean yield of genotypes across nine environments ranged from $1539 \mathrm{~kg} \mathrm{ha}^{-1}$ at Dhera in 2018 to $7622 \mathrm{~kg} \mathrm{ha}^{-1}$ at Kulumsa in 2018, respectively. The recorded mean yield of the standard checks; Daka (5067 $\mathrm{kg} \mathrm{ha}^{-1}$ ) and Ogolcho (4018 $\mathrm{kg} \mathrm{ha}^{-1}$ ) were below the grand mean yield of genotypes across environments implying the possibility to select superior candidate genotypes better than the st. check varieties. The Genotypes ETBW 9136 (5732 $\left.\mathrm{kgha}^{-1}\right)$, ETBW 9139 (5845 kg ha $\left.{ }^{-1}\right)$, ETBW 9646 (5754 kg ha-1), ETBW9172 (5634 $\left.\mathrm{kgha}^{-1}\right)$, ETBW9641 (5545 $\mathrm{kgha}^{-1}$ ), ETBW 9080 (5545 $\mathrm{kgha}^{-1}$ ) and ETBW9396 $\left(5467 \mathrm{kgha}^{-1}\right)$ gave the highest mean grain yield across environments, whereas the standard check Ogolcho recorded lowest mean grain yield across environments (Table 4).

\subsection{AMMI Stability Value (ASV) and Yield Selection Index (YSI)}

The genotype with lower ASV values is considered more stable and genotypes with higher ASV are unstable. The analysis using AMMI stability value revealed that ETBW 9172 (7.30), ETBW 9396 (6.18), ETBW 9452 (4.77), ETBW 9646 (4.93), ETBW 9651 (9.89), ETBW 9652
(2.99), ETBW 9139 (4.21) and ETBW 9077 (8.47) were among genotypes with lower ASV values, indicating those genotypes were more stable than the others. However, the genotype OGOLCHO (102.08), ETBW 9119 (38.89), ETBW 9065 (31.31), ETBW 9545 (28.28) had the highest AMMI stability values inferring those genotypes were classified under the least stable genotypes. Stability is not the only parameter for selection, because the most stable genotypes would not necessarily give the best yield performance [14] hence there is the need to use the Yield Selection Index (YSI) which incorporate both mean yield and stability of genotypes. It was applied to identify high yielding and stable genotypes in cereal crops like maize [4] and durum wheat [14]. Accordingly, the Yield selection index revealed that the genotype ETBW 9139, ETBW 9646, ETBW 9396, and ETBW 9172 are the best and top-ranking genotypes integrating both stability and grain yield performance parameters. This result is also confirmed by conducting further analysis using the Eberhart and Russell regression model for the proper recommendation of the genotypes. The genotypes ETBW 9172, ETBW 9396, ETBW 9641, and ETBW 9646 had regression coefficients approaching one and deviation from regression approaching zero implying that they are stable and widely adaptable than the other genotypes which highly agreed with AMMI model. The genotypes ETBW 9396 and ETBW 9646 selected as high yielding and stable by AMMI model are also selected by Eberhart and Russell regression model (Table 5). 
Table 4. Mean grain yield $\left(\mathrm{kg} \mathrm{ha}^{-1}\right)$ performance of the 25 genotypes of bread wheat tested in nine environments.

\begin{tabular}{|c|c|c|c|c|c|c|c|c|c|c|}
\hline Genotype & KU18 & AA18 & DH18 & MK18 & AT18 & KU19 & AA19 & DH19 & MK19 & MEAN \\
\hline DAKA & 8040 & 5864 & 1818 & 1300 & 6317 & 6282 & 7759 & 4144 & 4074 & 5067 \\
\hline ETBW 9116 & 6991 & 5484 & 2746 & 1649 & 7012 & 6842 & 6446 & 4006 & 3874 & 5006 \\
\hline ETBW 9119 & 7012 & 6470 & 1923 & 1711 & 7205 & 5473 & 5536 & 4090 & 4090 & 4835 \\
\hline ETBW 9128 & 7417 & 4917 & 841 & 929 & 5708 & 7342 & 6808 & 4756 & 4419 & 4793 \\
\hline ETBW 9136 & 7708 & 6894 & 2377 & 2201 & 5995 & 7671 & 8123 & 5452 & 5164 & 5732 \\
\hline ETBW 9139 & 8100 & 6791 & 1114 & 2868 & 7375 & 7179 & 7932 & 4916 & 6329 & 5845 \\
\hline ETBW 9149 & 7412 & 5812 & 1343 & 1242 & 5838 & 7919 & 6188 & 4574 & 5113 & 5049 \\
\hline ETBW 9065 & 6731 & 7038 & 1086 & 1620 & 6998 & 5976 & 8386 & 5687 & 4879 & 5378 \\
\hline ETBW 9077 & 7232 & 4702 & 1921 & 2212 & 7555 & 6047 & 7273 & 4458 & 4817 & 5135 \\
\hline ETBW 9078 & 7703 & 4674 & 1271 & 2721 & 6127 & 6609 & 7040 & 4936 & 3721 & 4978 \\
\hline ETBW 9080 & 7706 & 6868 & 1713 & 2507 & 5100 & 7519 & 8186 & 4996 & 5314 & 5545 \\
\hline ETBW 9172 & 8301 & 6464 & 1913 & 2139 & 6775 & 6510 & 7360 & 5828 & 5416 & 5634 \\
\hline ETBW 9396 & 7827 & 6327 & 1167 & 2418 & 6360 & 7429 & 7210 & 5256 & 5211 & 5467 \\
\hline ETBW 9452 & 7903 & 5689 & 1031 & 2521 & 7045 & 6607 & 6982 & 5618 & 4986 & 5376 \\
\hline ETBW 9543 & 7714 & 6280 & 1449 & 1629 & 7732 & 6290 & 7044 & 4110 & 4542 & 5199 \\
\hline ETBW 9545 & 8314 & 5428 & 1089 & 1158 & 6408 & 7382 & 8202 & 4591 & 3914 & 5165 \\
\hline ETBW 9641 & 7788 & 5943 & 1852 & 2547 & 6942 & 6308 & 8393 & 5063 & 5114 & 5550 \\
\hline ETBW 9642 & 8157 & 5210 & 1240 & 1993 & 6778 & 7319 & 7747 & 4788 & 5240 & 5386 \\
\hline ETBW 9646 & 8397 & 5972 & 1706 & 2697 & 6825 & 6909 & 7653 & 5979 & 5649 & 5754 \\
\hline ETBW 9647 & 7731 & 4280 & 1564 & 2727 & 6708 & 7512 & 7688 & 4357 & 5916 & 5387 \\
\hline ETBW 9648 & 8394 & 6279 & 2484 & 2380 & 6637 & 6093 & 7974 & 5567 & 5598 & 5712 \\
\hline ETBW 9650 & 7992 & 4559 & 1188 & 1512 & 7685 & 6874 & 7409 & 5249 & 5320 & 5310 \\
\hline ETBW 9651 & 6919 & 6306 & 1021 & 1369 & 5845 & 6549 & 7004 & 3709 & 4977 & 4855 \\
\hline ETBW 9652 & 7467 & 5510 & 1424 & 1594 & 6743 & 7053 & 7174 & 4502 & 4638 & 5123 \\
\hline OGOLCHO & 5590 & 4072 & 1200 & 792 & 7027 & 6484 & 1558 & 4279 & 5163 & 4018 \\
\hline Mean & 7622 & 5753 & 1539 & 1937 & 6670 & 6807 & 7163 & 4836 & 4939 & 5252 \\
\hline CV (\%) & 5.92 & 13.42 & 31.06 & 47.13 & 13.70 & 13.18 & 8.21 & 8.33 & 19.41 & 14.95 \\
\hline LSD $(5 \%)$ & 801 & 1391 & 1090 & ns & $\mathrm{ns}$ & $\mathrm{ns}$ & 966 & 677 & ns & \\
\hline
\end{tabular}

Note: KU18- Kulumsa 2018; AA18_ Asasa 2018; DH18_ Dhera 2018; MK18_ Melkasa 2018; AT18_ Atsela 2018; KU19_ Kulumsa 2019; AA19_ Asasa 2019; DH19 Dhera 2019; MK19_ Melkasa 2019.

Table 5. Stability parameters and the rank of genotypes tested for grain yield.

\begin{tabular}{|c|c|c|c|c|c|c|c|}
\hline S/No. & Genotype & bij & $\mathbf{S}^{2}$ dij & ASV & YSI & Mean grain yield $\left(\mathrm{kg} \mathrm{ha}^{-1}\right)$ & Y rank \\
\hline 1 & DAKA & 1.06 & 106253.30 & 21.50 & 37 & 5067 & 8 \\
\hline 2 & ETBW 9116 & 0.86 & 251329.72 & 18.29 & 37 & 5006 & 6 \\
\hline 3 & ETBW 9119 & 0.86 & 466019.18 & 38.90 & 47 & 4835 & 3 \\
\hline 4 & ETBW 9128 & 1.10 & 16019.92 & 17.82 & 39 & 4793 & 2 \\
\hline 5 & ETBW 9136 & 0.97 & 154110.38 & 16.49 & 16 & 5732 & 23 \\
\hline 6 & ETBW 9139 & 1.07 & 103245.50 & 4.21 & 3 & 5845 & 25 \\
\hline 7 & ETBW 9149 & 1.03 & 241996.10 & 18.18 & 35 & 5049 & 7 \\
\hline 8 & ETBW 9065 & 1.06 & 576631.12 & 31.32 & 34 & 5378 & 15 \\
\hline 9 & ETBW 9077 & 0.92 & 167188.90 & 8.47 & 23 & 5135 & 10 \\
\hline 10 & ETBW 9078 & 0.93 & 195231.34 & 11.05 & 30 & 4978 & 5 \\
\hline 11 & ETBW 9080 & 0.97 & 505655.56 & 27.75 & 28 & 5545 & 19 \\
\hline 12 & ETBW 9172 & 0.98 & -37970.73 & 7.30 & 11 & 5634 & 21 \\
\hline 13 & ETBW 9396 & 1.02 & -57483.87 & 6.18 & 13 & 5467 & 18 \\
\hline 14 & ETBW 9452 & 1.00 & -9718.48 & 4.77 & 15 & 5376 & 14 \\
\hline 15 & ETBW 9543 & 1.07 & 118148.19 & 17.46 & 28 & 5199 & 12 \\
\hline 16 & ETBW 9545 & 1.22 & 78965.93 & 28.28 & 37 & 5165 & 11 \\
\hline 17 & ETBW 9641 & 0.98 & 27637.70 & 18.81 & 24 & 5550 & 20 \\
\hline 18 & ETBW 9642 & 1.10 & -87313.60 & 15.84 & 22 & 5386 & 16 \\
\hline 19 & ETBW 9646 & 0.99 & -54204.30 & 4.94 & 6 & 5754 & 24 \\
\hline 20 & ETBW 9647 & 0.97 & 446791.96 & 25.59 & 29 & 5387 & 17 \\
\hline 21 & ETBW 9648 & 0.92 & 75084.50 & 14.38 & 15 & 5712 & 22 \\
\hline 22 & ETBW 9650 & 1.12 & 177172.22 & 13.58 & 23 & 5310 & 13 \\
\hline 23 & ETBW 9651 & 1.03 & 79368.60 & 9.89 & 30 & 4855 & 4 \\
\hline 24 & ETBW 9652 & 1.05 & -170007.71 & 2.99 & 18 & 5123 & 9 \\
\hline 25 & OGOLCHO & 0.71 & 3153092.50 & 102.09 & 50 & 4018 & 1 \\
\hline
\end{tabular}




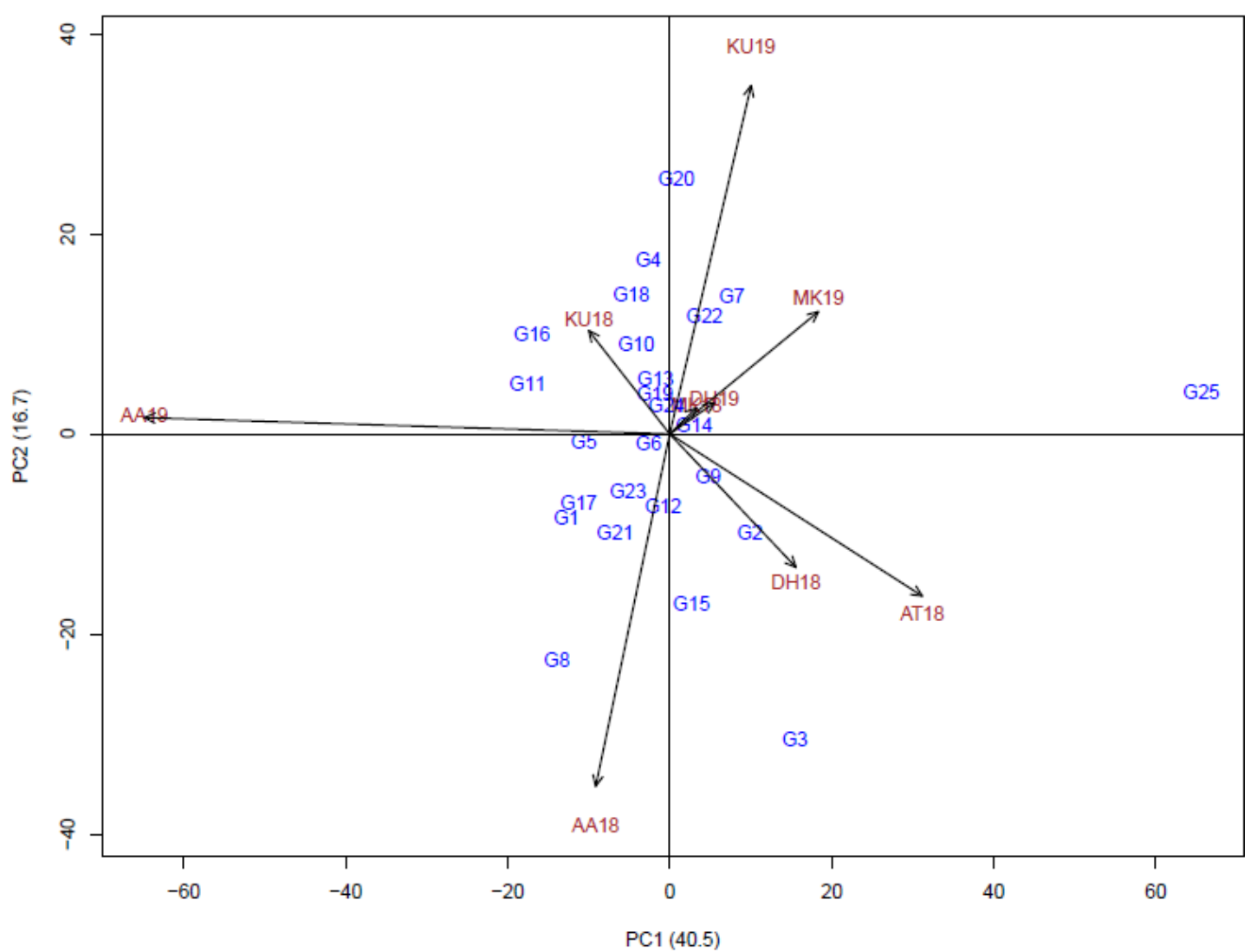

Figure 1. GGE biplot analysis for the first two IPCA scores of the genotype $x$ environment interaction for mean grain yield.

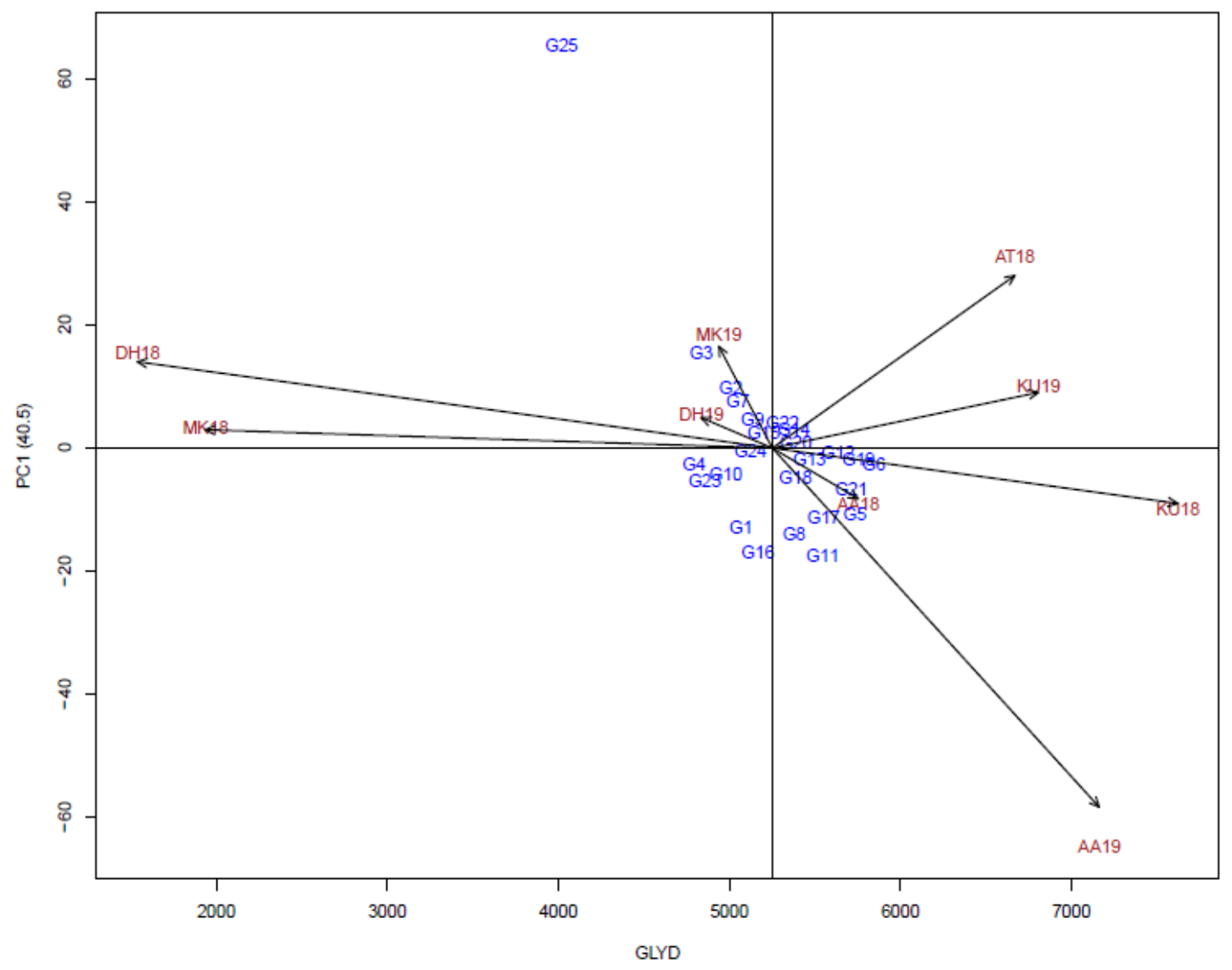

Figure 2. GGE biplot analysis for the mean yield $\left(\mathrm{kg} \mathrm{ha}^{-1}\right)$ with first IPCA score of the genotype x environment interaction. 


\subsection{Mean Performance of the Genotypes for Other Important Agronomic Traits}

A mean for days to heading of genotypes was ranged from 57 to 65 days with an average value of 60.11 days which indicates almost all genotype had the narrow range of heading dates. Similarly, there was little difference between genotypes for days to maturity confirming that the tested genotypes can be categorized under similar maturity groups. Plant height varied from 82 to $93 \mathrm{~cm}$ with minimum values in genotypes ETBW 9651 and the maximum was for ETBW 9646. The mean 1000 kernel weight ranged from $28 \mathrm{~g}$ (ETBW 9396 and OGOLCHO) to $38 \mathrm{~g}$ (ETBW 9545) with an average value of $32.75 \mathrm{~g}$. The genotype ETBW 9545 (22.5\% and 35\%), ETBW $9647(19 \%$ and 32\%) ETBW 9080 (19\% and 32\%) had TKW advantage than the st. checks DEKA and OGOLCHO, respectively. Hectoliter weight provides a rough estimate of flour yield potential in wheat and is important to millers just as grain yield is important to wheat producers. The value the trait ranged from $64 \mathrm{~kg} / \mathrm{hl}$ (OGOLCHO) to $69 \mathrm{hg} / \mathrm{hl}$ (ETBW 9136, ETBW 9080, ETBW 9646 and ETBW 9651) (Table 6).

Table 6. Combined mean performance of bread wheat for some important agronomic traits tested across 9 environments from 2018 to 2019 cropping seasons.

\begin{tabular}{|c|c|c|c|c|c|c|}
\hline S/No & Genotype & DTH & DTM & PHT (cm) & TKW (g) & HLW (kg/hl) \\
\hline 1 & DEKA & 62 & 110 & 89 & 31 & 66 \\
\hline 2 & ETBW 9116 & 65 & 110 & 86 & 31 & 67 \\
\hline 3 & ETBW 9119 & 63 & 110 & 86 & 29 & 67 \\
\hline 4 & ETBW 9128 & 61 & 110 & 85 & 30 & 66 \\
\hline 5 & ETBW 9136 & 60 & 107 & 91 & 35 & 69 \\
\hline 6 & ETBW 9139 & 58 & 107 & 85 & 34 & 68 \\
\hline 7 & ETBW 9149 & 60 & 108 & 85 & 35 & 67 \\
\hline 8 & ETBW 9065 & 58 & 108 & 90 & 32 & 68 \\
\hline 9 & ETBW 9077 & 60 & 109 & 83 & 31 & 68 \\
\hline 10 & ETBW 9078 & 60 & 108 & 84 & 30 & 68 \\
\hline 11 & ETBW 9080 & 59 & 108 & 87 & 37 & 69 \\
\hline 12 & ETBW 9172 & 61 & 108 & 86 & 32 & 68 \\
\hline 13 & ETBW 9396 & 59 & 107 & 83 & 28 & 68 \\
\hline 14 & ETBW 9452 & 59 & 108 & 84 & 36 & 68 \\
\hline 15 & ETBW 9543 & 59 & 110 & 83 & 32 & 67 \\
\hline 16 & ETBW 9545 & 57 & 107 & 83 & 38 & 68 \\
\hline 17 & ETBW 9641 & 60 & 108 & 91 & 36 & 67 \\
\hline 18 & ETBW 9642 & 60 & 108 & 89 & 35 & 68 \\
\hline 19 & ETBW 9646 & 60 & 109 & 93 & 36 & 69 \\
\hline 20 & ETBW 9647 & 60 & 109 & 89 & 37 & 68 \\
\hline 21 & ETBW 9648 & 59 & 109 & 90 & 32 & 68 \\
\hline 22 & ETBW 9650 & 60 & 108 & 89 & 34 & 68 \\
\hline 23 & ETBW 9651 & 58 & 107 & 82 & 31 & 69 \\
\hline 24 & ETBW 9652 & 61 & 110 & 86 & 29 & 67 \\
\hline 25 & OGOLCHO & 62 & 109 & 92 & 28 & 64 \\
\hline Mean & & 60.11 & 108.43 & 86.89 & 32.75 & 67.63 \\
\hline $\operatorname{LSD}(5 \%)$ & & 1.81 & 1.98 & 3.50 & 2.81 & 2.00 \\
\hline CV (\%) & & 4.10 & 2.07 & 6.78 & 9.69 & 2.57 \\
\hline
\end{tabular}

Note: DH=Days to $75 \%$ heading; DM=Days to $95 \%$ maturity; PHT=Plant height $(\mathrm{cm})$; TKW=Thousand kernel weight (g); HLW=Hectoliter weight; $\mathrm{YLD}=$ Grain Yield $(\mathrm{t} / \mathrm{h}$

\subsection{Severity and Response of Genotypes to Yellow and Stem Rust}

The level of severity values and response were slightly different at each location and years indicating that the level of the rust's disease severity is dependent on the suitability of the environments. As was indicated by the Yield selection index the genotype, ETBW 9646, ETBW 9396, and ETBW 9172 were stable and top-yielding genotypes. But except ETBW 9396 the top-ranking and stable genotype have weak resistance to yellow and stem rust when the environment is appropriate for the occurrence of the disease. The degree of wheat susceptibility to yellow rust varied across locations due to variation in virulence spectra of the pathogen and climatic conditions for the pressure [17]. The highest yellow and stem rust disease score observed in the 2019 cropping season at kulumsa indicating this environment was highly suitable for buildup of both yellow and stem rust disease (Table 7). Among the studied genotypes relatively showed the best stability and score high mean grain yield; the genotype ETBW 9080 and ETBW 9396 were relatively recorded low yellow rust and stem rust score over location and years. These two genotypes were selected and proposed for variety verification and possible release in 2020 . 
Table 7. Mean severity percentage of yellow rust and stem rust on 25 bread wheat genotypes.

\begin{tabular}{|c|c|c|c|c|c|c|c|c|c|}
\hline S/No. & Genotype & KU18YR & KU18Sr & AA18Yr & AA18Sr & MK18Sr & KU19Yr & KU19Sr & AA19Yr \\
\hline 1 & DEKA & 1MRMS & 5MSMR & 5MSMR & 15MSMR & 15SMS & $30 \mathrm{MSS}$ & $50 \mathrm{~S}$ & $15 \mathrm{MSMR}$ \\
\hline 2 & ETBW 9116 & 0 & $1 \mathrm{MS}$ & 5MSMR & 5MSMR & 10SMS & 5MSMR & $40 \mathrm{~S}$ & $1 \mathrm{MR}$ \\
\hline 3 & ETBW 9119 & $5 \mathrm{MS}$ & 10MSS & 10MSS & $10 \mathrm{MR}$ & $15 \mathrm{~S}$ & $60 \mathrm{~S}$ & $50 \mathrm{~S}$ & 10MRMS \\
\hline 4 & ETBW 9128 & 5MSMR & $5 \mathrm{~S}$ & 5MSMR & $60 \mathrm{~S}$ & $20 \mathrm{~S}$ & $50 \mathrm{~S}$ & $50 \mathrm{~S}$ & $5 \mathrm{MS}$ \\
\hline 5 & ETBW 9136 & $1 \mathrm{MR}$ & $5 \mathrm{~S}$ & 5MSMR & 40MSS & 15SMS & 5MSMR & $50 \mathrm{~S}$ & 5MRMS \\
\hline 6 & ETBW 9139 & $5 \mathrm{MR}$ & 10MSS & 10MSMR & 20MSS & 154SMS & $60 \mathrm{~S}$ & $50 \mathrm{~S}$ & $15 \mathrm{~S}$ \\
\hline 7 & ETBW 9149 & $5 \mathrm{MR}$ & $1 \mathrm{MS}$ & 1MSMR & $5 \mathrm{MR}$ & 5MSMR & 5MSMR & $40 \mathrm{~S}$ & $5 \mathrm{MS}$ \\
\hline 9 & ETBW 9077 & 30MSS & $1 \mathrm{MS}$ & 10MSS & 20MSMR & 10MRMS & $40 \mathrm{~S}$ & $40 \mathrm{~S}$ & $10 \mathrm{MS}$ \\
\hline 10 & ETBW 9078 & 5MSMR & 0 & 10MSMR & 10MSMR & 5MSMR & $15 \mathrm{MSS}$ & $50 \mathrm{~S}$ & $15 \mathrm{MS}$ \\
\hline 11 & ETBW 9080 & $1 \mathrm{MR}$ & $5 \mathrm{MS}$ & 1MSMR & 10MSMR & $15 \mathrm{SMS}$ & 10MSMR & $15 \mathrm{MSS}$ & $5 \mathrm{MR}$ \\
\hline 12 & ETBW 9172 & 5MRMS & $5 \mathrm{MSS}$ & 5MSMR & 10MSMR & 10MSMR & 15MSMR & $50 \mathrm{~S}$ & $1 \mathrm{MR}$ \\
\hline 13 & ETBW 9396 & 5MRMS & 0 & 1MSMR & 1RMR & 1MRMS & $1 \mathrm{MR}$ & $15 \mathrm{~S}$ & 5MSMR \\
\hline 14 & ETBW 9452 & $1 \mathrm{MR}$ & 0 & 15MSMR & 0 & 1MRMS & $60 \mathrm{~S}$ & $40 \mathrm{~S}$ & $1 \mathrm{MR}$ \\
\hline 15 & ETBW 9543 & 15MRMS & 0 & 20MSS & 10MRMS & 5MSMR & $50 \mathrm{~S}$ & $30 \mathrm{~S}$ & 10MSS \\
\hline 16 & ETBW 9545 & 15MRMS & $1 \mathrm{MR}$ & 15MSMR & $10 \mathrm{MS}$ & 1MRMS & 5MSMR & $50 \mathrm{~S}$ & $10 \mathrm{MS}$ \\
\hline 18 & ETBW 9642 & $1 \mathrm{MR}$ & 10MSS & 5MSMR & $60 \mathrm{~S}$ & $15 \mathrm{SMS}$ & 5MSMR & $70 \mathrm{~S}$ & $1 \mathrm{MR}$ \\
\hline 19 & ETBW 9646 & $1 \mathrm{MR}$ & $20 \mathrm{~S}$ & 5MSMR & 40MSS & $30 \mathrm{~S}$ & 10MSMR & $70 \mathrm{~S}$ & 1MRMS \\
\hline 20 & ETBW 9647 & $1 \mathrm{MR}$ & $10 \mathrm{~S}$ & 5MSMR & $70 \mathrm{~S}$ & $30 \mathrm{~S}$ & $15 \mathrm{MSS}$ & $50 \mathrm{~S}$ & 1MSMR \\
\hline 21 & ETBW 9648 & 5MRMS & $15 \mathrm{~S}$ & 10MSMR & 10RMR & 1MRMS & $60 \mathrm{~S}$ & 30MSS & $15 \mathrm{MS}$ \\
\hline 22 & ETBW 9650 & 1MSMR & $15 \mathrm{~S}$ & 5MSMR & $60 \mathrm{~S}$ & $20 \mathrm{~S}$ & $60 \mathrm{~S}$ & $30 \mathrm{~S}$ & $1 \mathrm{MR}$ \\
\hline 23 & ETBW 9651 & $5 \mathrm{MR}$ & 1MSMR & 5MSMR & $20 \mathrm{MS}$ & 1MRMS & $60 \mathrm{~S}$ & $30 \mathrm{~S}$ & 5MSMR \\
\hline 24 & ETBW 9652 & 5MRMS & 1MSMR & 5MSMR & 10MRMS & 5SMS & $60 \mathrm{~S}$ & $60 \mathrm{~S}$ & 10MSMR \\
\hline 25 & OGOLCHO & 10MSMR & $40 \mathrm{~s}$ & 20MSMR & $50 \mathrm{~S}$ & $30 \mathrm{~S}$ & $40 \mathrm{~S}$ & $70 \mathrm{~S}$ & $90 \mathrm{~S}$ \\
\hline
\end{tabular}

Note: $\mathrm{Yr}=$ Yellow rust, $\mathrm{Sr}=\mathrm{Stem}$ rust, $\mathrm{KU}=$ kulumsa, $\mathrm{AA}=$ Asasa, MK=Melkasa, $\mathrm{R}-$ Resistant, MR- Moderately resistant, MS- Moderately susceptible, $\mathrm{S}$ Susceptible

\section{Conclusion}

Due to changes in climatic factors and/or weather variabilities, most of the wheat producing regions in Ethiopia became low moisture stress areas. Hence, there is a need to develop varieties which could adapt to this short growing cycles. In view of this 25 bread wheat genotypes including two st. checks were evaluated in 9 environments from 2018 to 2019 cropping seasons with the objectives to estimate the magnitude of genotype by environment interaction and to select stable and adaptable varieties across the tested environments. The combined analysis of variance showed a highly significant $(\mathrm{p} \leq 0.01)$ differences among the genotypes, environments, and GEI for grain yield suggesting a differential response of genotypes across testing environments. The grand mean yield over nine environments was $5252 \mathrm{~kg} \mathrm{ha}^{-1}$ and the mean yield of genotypes across nine environments ranged from $1539 \mathrm{~kg} \mathrm{ha}^{-1}$ in 2018 at Dhera to $7622 \mathrm{~kg} \mathrm{ha}^{-1}$ in 2018 at Kulumsa. The genotypes ETBW $9136\left(5732 \mathrm{~kg} \mathrm{ha}^{-1}\right)$, ETBW $9139\left(5845 \mathrm{~kg} \mathrm{ha}^{-1}\right)$, ETBW $9646\left(5754 \mathrm{~kg} \mathrm{ha}^{-1}\right)$, ETBW9172 (5634 kg ha-1), ETBW9641 (5545 kg ha-1), ETBW $9080\left(5545 \mathrm{~kg} \mathrm{ha}^{-1}\right)$ and ETBW9396 $\left(5467 \mathrm{~kg} \mathrm{ha}^{-1}\right)$ gave the highest mean grain yield across environments, whereas the standard check Ogolcho recorded lowest mean grain yield across environments. The first four principal components of the GEI explained $85.6 \%$ of the total variations. Additive main effects and multiplicative interaction (AMMI) stability parameters revealed that the genotypes ETBW 9080 (G11), ETBW 9172 (G12), ETBW 9646 (G19), ETBW 9396 (G13), ETBW 9452
(G14), ETBW 9136 (G5) and ETBW 9139 (G6) were high yielders and more stable inferring little interaction of genotypes with the environment whereas Ogolcho (G25), ETBW 9119 (G3), ETBW 9647 (G20) and ETBW 9065 (G8) was low yielder and unstable suggesting high interaction with the environments. Based on the results of grain yield stability parameters and other agronomic traits including diseases resistances, the genotypes viz. ETBW 9396 (G13) and ETBW 9080 (G11), were selected for candidate varieties for variety verification and possible release in 2021 for low moisture stress areas of Ethiopia.

\section{Acknowledgements}

The authors are grateful to the EIAR/Kulumsa Agricultural Research Center for financing the project and collaborative centers for planting the seeds, managing the trials and collecting the data.

\section{References}

[1] Adugna, W. \& Labuschagne, M. T., 2002. Genotypeenvironment interactions and phenotypic stability analyses of linseed in Ethiopia. Plant Breeding 121, 66-71.

[2] Bradu, D., and K. R. Gabriel. 1978. The biplot as a diagnostic tool for models of two-way tables. Technometrics 20: 47-68.

[3] Central Statistical Agency. CSA. 2018. Agricultural sample survey 2017/18 (2010 E.C.) Volume 1. Report on area and production of major crops (Private peasant holdings, Mehere season). Statistical Bulletin 586. Addis Ababa, Ethiopia. 
[4] Eberhart, S. A. and Russell, W. A. 1966. Stability parameter for comparing varieties. Crop Science 6: 36-40.

[5] Falconer DS. 1952. The problem of environment and selection. The American Naturalist. 86: 293-298.

[6] Fan, X.-M., M. S. Kang, H. Chen, Y. Zhang, J. Tan and C. Xu. 2007. Yield Stability of Maize Hybrids Evaluated in Multi Environment Trials in Yunnan, China. Agronomy Journal, 99: 220 .

[7] Farshadfar E (2008) Incorporation of AMMI stability value and grain yield in a single non-parametric index (GSI) in bread wheat. Pak J Biol Sci 11 (14): 1791-1796.

[8] Fernandez GCJ. 1991. Analysis of genotype x environment interaction by stability estimates. Hort Science.; 26: 947-950.

[9] Gashaw Tadesse Abate, Bernard, T. de Brauw, A. and Minot N. 2018. The impact of the use of new technologies on farmers' wheat yield in Ethiopia: evidence from a randomized control trial. Agric Econ. 49 (4): 409-421.

[10] Gauch, H. G. and Zobel, R. W. 1996. AMMI analysis of yield trials. In: Genotype by Environment Interaction, pp. 85-122, Boca Raton. CRC Press, New York.

[11] Gauch, H. G. and R. W. Zobel. 1988 Predictive and postdictive success of statistical analyses of yield trials. Theor. Appl. Genet. 76: 1-10.

[12] Getachew Agegnehu, Amare Ghizaw, Woldeyesus Sinebo. 2008. Yield potential and land-use efficiency of wheat and faba bean mixed intercropping. Agron. Sustain. Dev. 28: $257-$ 263. DOI: 10.1051/agro: 2008012.
[13] Ministry of Agriculture and Natural Resources. 2018. Plant Variety Release, Protection and Seed Quality Control Directorate, Crop Variety Register, Issue No. 21, Addis Ababa, Ethiopia.

[14] Mohammadi, R., M. Roostaei, Y. Ansari, M. Aghaee and A. Amri. 2010. Relationships of phenotypic stability measures for genotypes of three cereal crops. Canadian Journal of Plant Science, 90: 819-30.

[15] Peterson F, Campbell B, Hannah E. 1948. A diagrammatic scale for estimating rust intensity on leaves and stems of cereals. Can. J. Res. 26: 496-500.

[16] Purchase, J. L. 1997. Parametric analysis to describe GxE interaction and yield stability in winter wheat. $\mathrm{PhD}$. Thesis, Department of Agronomy, Faculty of Agriculture, University of the Orange Free State, Bloemfontein, South Africa.

[17] Wubishet A., Chemeda F. and Bekele H. 2015. Effects of environment on epidemics of yellow rust (Puccinia striiformis West.) of bread wheat (Triticum aestivum L.) in Bale highlands, South-Eastern Ethiopia. Global Journal of Pests, Diseases and Crop Protection, 3 (2): 096-107.

[18] Wubshet Alemu and Chemeda Fininsa. 2016. Effects of Environment on Wheat Varieties' Yellow Rust Resistance, Yield and Yield Related Traits in South-Eastern Ethiopia. Plant, $4 \quad$ (3): 14-22; http://www.sciencepublishinggroup.com/j/plant; doi: 10.11648/j.plant.20160403.11; ISSN: 2331-0669 (Print); ISSN: 2331-0677 (Online).

[19] Yan, W. and L. A. Hunt. 1998. Genotype by environment interaction and crop yield. Plant Breed. Rev. 16: 135-178. 